\title{
Management of Hospital Formularies in Ontario: Challenges within a Local Health Integration Network
}

\author{
Natasha Burke, James M Bowen, Sue Troyan, Jathishinie Jegathisawaran, Carolyn Gosse, \\ Marita Tonkin, Sandra Kagoma, Ron Goeree, and Anne Holbrook
}

\begin{abstract}
Background: Expenditures on drugs dispensed and administered to patients in Canadian hospitals have been estimated at $\$ 2.4$ billion per year. Pharmacy and therapeutics (P\&T) committees play a key role in the evaluation and management of drug therapies in this setting. Hospitals differ with respect to the composition of these committees, their members' expertise, and the processes used for making formulary decisions.

Objectives: To examine the current processes for formulary drug review from the perspective of P\&T committees and their individual members, and to examine the needs and preferences of these stakeholders related to evidence review and potential collaborative drug review processes within a large Local Health Integration Network (LHIN) in Ontario.

Methods: Twenty-three sites within 10 hospital corporations in LHIN 4 (Hamilton Niagara Haldimand Brant) were recruited. A 2-part questionnaire was developed and pretested for clarity and comprehensiveness. The institution profile section of the questionnaire was to be completed by pharmacy directors and the P\&T section by committee members.

Results: Ten pharmacy directors and 28 committee members representing 10 P\&T committees responded. A mean of 6.4 new drug requests were reviewed annually by each P\&T committee. Across the LHIN, the workload associated with reviewing submissions for new drugs to be added to the formulary represented 0.84 full-time equivalent. The quality of clinical evidence in the drug submissions was rated more favourably than the quality of economic evidence; furthermore, the use of economic evidence was limited by a lack of health economics expertise within the committees. A centralized review process for the LHIN was perceived as beneficial to improve efficiency, the quality of review, and standardization, and also to reduce costs.
\end{abstract}

Conclusions: Across the Hamilton Niagara Haldimand Brant LHIN, considerable time and resources are spent on the review of potential new drugs for addition to the hospitals' formularies. A standardized formulary review process, with greater use of provincial and national drug reviews, would likely benefit all LHINs.

Keywords: pharmacy and therapeutics committee, hospital formulary, decision-making, pharmacoeconomics, survey, Canada

\section{RÉSUMÉ}

Contexte : Les dépenses pour les médicaments distribués et administrés aux patients dans les hôpitaux canadiens ont été évaluées à 2,4 milliards de dollars par année. Les comités de pharmacologie et de thérapeutique jouent un rôle central dans l'analyse et la prise en charge des pharmacothérapies dans ce milieu. La composition de ces comités et l'expertise de leurs membres varient d'un hôpital à l'autre, tout comme les processus qui y sont employés pour prendre des décisions à propos de la liste des médicaments.

Objectifs : Étudier les processus actuels d'ajout de médicaments à la liste locale du point de vue des comités de pharmacologie et de thérapeutique et de leurs membres. Examiner les besoins et préférences de ces parties prenantes quant à l'analyse des données probantes et aux potentiels processus collaboratifs d'évaluation des médicaments au sein d'un important réseau local d'intégration des services de santé (RLISS) ontarien.

Méthodes : Vingt-trois établissements dans 10 organisations hospitalières du RLISS 4 (Hamilton Niagara Haldimand Brant) ont été retenus. On a élaboré un questionnaire de deux parties qui a été testé au préalable pour en vérifier la clarté et l'exhaustivité. La section sur le profil de l'établissement devait être remplie par les directeurs de pharmacie et celle sur la pharmacologie et la thérapeutique devait l'être par les membres des comités.

Résultats : Dix directeurs de pharmacie et 28 membres représentant 10 comités de pharmacologie et de thérapeutique ont répondu. En moyenne, 6,4 nouvelles demandes d'ajout de médicament étaient analysées annuellement par chaque comité. Dans l'ensemble du RLISS, la charge de travail nécessaire à l'analyse des demandes d'ajout de nouveaux médicaments à la liste locale représentait 0,84 d'un poste équivalent temps plein. La qualité des données cliniques probantes dans les demandes d'ajout était considérée plus favorablement que celle des données économiques. De plus, comme les membres des comités ne possédaient pas l'expertise nécessaire en économie de la santé, l'utilisation des données probantes à ce sujet était limitée. Un processus centralisé d'analyse pour le RLISS était perçu comme avantageux pour améliorer l'efficience, la qualité de l'analyse et la normalisation ainsi que pour réduire les coûts.

Conclusions : Dans l'ensemble du RLISS de Hamilton Niagara Haldimand Brant, beaucoup de ressources et de temps sont accordés à 


\section{Can J Hosp Pharm. 2016;69(3):187-93}

évaluer l'ajout de médicaments à la liste locale. Tous les RLISS tireraient sûrement profit d'un processus normalisé d'ajout à la liste locale des médicaments ainsi que d'une meilleure utilisation des évaluations réalisées par les organismes provinciaux et national.

Mots clés : comité de pharmacologie et de thérapeutique, liste locale des médicaments, prise de décision, pharmacoéconomie, sondage, Canada

\section{INTRODUCTION}

Spending on prescription drugs in the outpatient setting in Canada accounted for an estimated $13 \%$ of health expenditures in 2014 , or $\$ 28$ billion, with $\$ 12.1$ billion of this financed by the public sector. ${ }^{1}$ In addition to drugs funded through provincial drug programs, the public sector also finances drugs dispensed and administered to patients in hospitals. In 2009, hospital drug expenditures were estimated at $\$ 2.4$ billion. $^{2}$

As funding models increasingly focus on cost-effective care, hospital decision-makers face difficult choices on how to best allocate resources while working within fixed hospital budgets. ${ }^{3}$ Optimal utilization of costly hospital medications can be improved by employing a rational, evidence-based process, such as health technology assessment. This methodology provides a systematic, transparent, multidisciplinary approach to evaluating the benefits, harms, budget impact, and opportunity costs of drugs and other health technologies. In Canada, well-established processes for health technology assessment are used at the national and provincial levels to evaluate new drug technologies and provide recommendations to federal, provincial, and territorial public drug plans. ${ }^{4}$ However, although hospitals represent the most expensive sector of health care, they are typically not part of this high-quality review process. ${ }^{5}$

In many regions across Canada, individual hospitals make decisions on the approval and use of drugs available to patients within the hospital. ${ }^{6}$ Pharmacy and therapeutics (P\&T) committees play an important role in the evaluation of drug therapies for addition to or removal from the hospital formulary and in establishing medication-use policies and procedures. ${ }^{7}$ P\&T committees are mandated by hospital accreditation standards, but differ in terms of responsibilities, membership, operation, and processes for formulary decision-making. ${ }^{8-11} \mathrm{~A}$ survey of Canadian hospitals in 2006 identified efficacy and safety of drugs as the primary review targets, with fewer than half of the committees reporting use of economic criteria. ${ }^{11}$ In Ontario, improving formulary management across hospitals using provincial review processes and price negotiation mechanisms was part of the Transparent Drug System for Patients Act, ${ }^{12}$ but this legislation has yet to be enacted, despite broad support from the pharmacy directors of teaching hospitals.

Since these planned initiatives began, the governance of health care in Ontario has changed markedly with the estab- lishment of 14 Local Health Integration Networks (LHINs) across the province in $2008 .{ }^{13,14}$ The LHINs are responsible for the planning, integration, and funding of local health services, including hospitals, community care, long-term care, and mental health services. The Hamilton Niagara Haldimand Brant (HNHB) LHIN (www.hnhblhin.on.ca), the third largest LHIN in Ontario, serves a population of 1.4 million people and, at the time of this study, included 10 hospital corporations, with some of the corporations having multiple hospital sites. Each corporation has its own P\&T committee, and these committees are independent of the LHIN administration. Little has been published about the evolution of hospital formulary decisionmaking, current processes of P\&T committees and their modern structure, or current opinions about coordinating or centralizing formulary drug review at a regional level. The objective of this study was to examine the current processes for formulary drug review from the perspective of P\&T committees and their individual members, and to examine the needs and preferences of these stakeholders related to evidence review and potential collaborative drug review processes within the HNHB LHIN.

\section{METHODS}

A cross-sectional survey of P\&T committee members across hospitals within the HNHB LHIN was conducted in September 2011 using a 2-part questionnaire. Development of this questionnaire took into account domains identified from the literature. ${ }^{8,9,11}$ The questionnaire was reviewed for clarity, comprehensiveness, and content validity by 8 study investigators, including pharmacy directors and clinicians. Part 1 of the questionnaire was an institution profile survey inquiring about (1) the institution's characteristics (number of sites, beds, and pharmacy staff), (2) its drug formulary (how clinicians access the formulary, major formulary reviews), (3) its P\&T committee (membership, frequency and duration of meetings, other activities performed), (4) the submission process for formulary review (prioritization of requests, use of standardized request forms), (5) the information and evidence submitted for review (clinical, economic, or other types of information), (6) formulary decision-making (method of decision-making, approval of requests), (7) approval and utilization of nonformulary drugs, and (8) recent requests for new drugs to be added to the formulary (drugs evaluated, sharing of reviews across institutions). 
This single copy is for your personal, non-commercial use only.

For permission to reprint multiple copies or to order presentation-ready copies for distribution, contact CJHP at cjhpedit@cshp.ca

Part 1 of the questionnaire was mailed to the director of pharmacy at each of the 10 hospital corporations.

Part 2 of the questionnaire was designed to gather feedback from individual P\&T committee members on their background and experience with drug reviews, their opinions and preferences regarding several components of their respective institutions' current processes for handling requests for new drugs to be added to the formulary (e.g., submission process for requests, quality of evidence submitted for review, expertise available to support decision-making, opinions on centralization of the review process). The director of pharmacy at each hospital was asked to distribute this part of the questionnaire to 4 or 5 individual P\&T committee members representing different professions at the hospital. This purposive sampling procedure was chosen to ensure equal representation from all of the hospitals and to obtain responses from each profession within the institutions, as well as to allow survey respondents to remain anonymous to the study investigators. Surveys were returned to the Programs for Assessment of Technology in Health (PATH) Research Institute, the coordinating centre, using iDataFax (DF/Net Research Inc, Seattle, Washington).

Survey results were summarized quantitatively using frequency tables, percentages, and descriptive statistics (mean, median, standard deviation [SD], range). Content analysis was used to identify common themes reported in responses to open-ended questions. Data from incomplete questionnaires were incorporated into the analysis.

Ethics approval for the study was obtained from the Hamilton Integrated Research Ethics Board (approval no. 113553). Respondents' consent was demonstrated by the return of completed questionnaires.

\section{RESULTS}

\section{Institution Profile Survey}

All 10 institution profile surveys were returned. Characteristics of the 10 hospital corporations within the HNHB LHIN are presented in Table 1. Four of the hospital corporations had more than one hospital site, for a total of 23 sites. The majority of sites offered both outpatient and inpatient services, with a total of 3566 beds. Of the 19 sites that provided inpatient services, 11 had more than 200 beds. Across the LHIN, pharmacy services were provided by 137 pharmacists, 201 pharmacy technicians, and 10 pharmacy administrative support staff.

\section{P\&T Committees}

All 10 hospital corporations had a committee that was responsible for the evaluation of formulary drug reviews. The number of committee members ranged from 5 to 17 , and $70 \%$ of committees had more than 10 members, for a total of 113 individuals across the LHIN (Table 1). Committee representa-
Table 1. Characteristics of Institutions and Pharmacy and Therapeutics Committees within the Hamilton Niagara Haldimand Brant Local Health Integration Network (LHIN)

\begin{tabular}{|c|c|}
\hline \multicolumn{2}{|l|}{ Characteristic } \\
\hline Institutions & \\
\hline Total institutions or hospital corporations & 10 \\
\hline Total sites & 23 \\
\hline \multicolumn{2}{|l|}{ Type of hospital } \\
\hline Community sites & 15 \\
\hline Academic sites & 8 \\
\hline \multicolumn{2}{|l|}{ Type of services by site } \\
\hline Inpatient services only & 2 \\
\hline Outpatient services only & 4 \\
\hline Both inpatient and outpatient services & 17 \\
\hline Total beds & 3566 \\
\hline \multicolumn{2}{|l|}{ Pharmacy and therapeutics committees* } \\
\hline Total committee members across LHIN & 113 \\
\hline \multicolumn{2}{|l|}{ Members per committee } \\
\hline Mean & 11.3 \\
\hline Median (range) & $12 \quad(5-17)$ \\
\hline \multicolumn{2}{|l|}{ Meetings per year } \\
\hline Mean & 7.7 \\
\hline Median (range) & $9 \quad(4-11)$ \\
\hline \multicolumn{2}{|l|}{ New drug requests reviewed annually } \\
\hline Mean & 6.4 \\
\hline Median (range) & $(2-15)$ \\
\hline
\end{tabular}

*Based on a total of 10 pharmacy and therapeutics committees (one for each corporation).

tion was mainly from medicine (mean $35 \%$, range $8 \%$ to $50 \%$ ), nursing (mean $29 \%$, range $6 \%$ to $60 \%$ ), and pharmacy (mean $25 \%$, range $8 \%$ to $50 \%$ ), with others from administration, infection control, laboratory medicine, nutrition, etc.

The frequency of meetings was 10 or more times per year for 4 of the corporations, 9 times per year for 2 corporations, 6 times per year for 1 corporation, and 4 times per year for 3 corporations. Six of the committees usually reviewed between 1 and 5 new drug requests annually, whereas 3 of the committees reviewed 10 or more requests per year (for an overall mean of 6.4 requests). Across the LHIN, an estimated 58 reviews were completed in a typical year, not accounting for duplication (i.e., review of the same drug) among committees. In a typical month, P\&T committee members across the LHIN spent a total of $137 \mathrm{~h}$ providing support for new formulary submissions and reviews, which could include both meetings and review of materials. When extrapolated to 1 year, this is equivalent to $1644 \mathrm{~h}$ or 0.84 full-time equivalent (FTE, where $1 \mathrm{FTE}=37.5 \mathrm{~h} /$ week or $1950 \mathrm{~h}$ ) spent by all P\&T committee members combined. Pharmacists provided $70 \%$ of the total hours of support for drug review activities, although 7 (70\%) of the committees reported that there was no dedicated personnel within the hospital to assist with the collection and synthesis of the information submitted. Five hospital corporations indicated that clinical pharmacists were expected to create or support formulary submissions in their clinical area of practice, with 3 hospital corporations using drug information or drug-use evaluation pharmacists to support 
formulary submissions. Pharmacists compiled some of the clinical evidence requested for a drug submission, in addition to physicians or the requester, whereas the economic information, such as hospital budget impact analysis, was compiled primarily by pharmacists.

In addition to reviewing applications for addition of a drug to the formulary, most P\&T committees performed other activities within the hospital, including development of policies related to therapeutic interchanges, drug-use policy, intravenous drug administration guidelines, and standardized order sets; medication-use evaluation; and adverse drug event monitoring and critical incident review. In addition to formulary drug review, half of the P\&T committees reported use of at least one subcommittee addressing specific therapeutic areas or medication-use processes, the most common being medication safety monitoring $(n=3)$, along with antimicrobial stewardship $(n=2)$, nursing/ pharmacy $(n=2)$, and accreditation-related medication management $(n=1)$. Of these subcommittees, 2 completed medicationuse evaluations, but none made direct formulary decisions. A major review of the drug formulary had been conducted within the past 10 years in 6 of the 10 hospital corporations.

\section{Formulary Review Submission Process}

The P\&T committees prioritized requests for additions to the formulary according to order of receipt, urgency, and needs of the patient population. A standardized form for requests for

\section{Table 2. Clinical, Economic, and Other Evidence Requested by Pharmacy and Therapeutics Committees as Part of New Formulary Drug Submissions}

\begin{tabular}{ll} 
Type of Evidence & $\begin{array}{c}\text { No. (\%) of } \\
\text { Committees }(\boldsymbol{n}=10)\end{array}$ \\
\hline Clinical & $7(70)$ \\
Description of target disease & $5(50)$ \\
Pharmacology and pharmacokinetics & $5(50)$ \\
Product and administration details & $8(80)$ \\
Efficacy & $6(60)$ \\
$\quad$ Summary (e.g., from product monograph) & $6(60)$ \\
$\quad$ Detailed (e.g., review of individual studies) & $7(70)$ \\
Safety & $7(70)$ \\
$\quad$ Summary (e.g., from product monograph) & $4(40)$ \\
Detailed (e.g., review of individual studies) & $3(30)$ \\
Formal critical appraisal of clinical evidence & \\
\hline Economic & $6(60)$ \\
Economic evaluation & $7(70)$ \\
$\quad$ e.g., cost-effectiveness) & $5(50)$ \\
Analysis of impact on hospital budget & $1(10)$ \\
Budget impact calculations & \\
Formal critical appraisal of & \\
economic evidence & $4(40)$ \\
Other & $5(50)$ \\
Institutional impact assessment & $1(10)$ \\
Drug plan coverage status & $5(50)$ \\
$\quad$ (e.g., Ontario Drug Benefit) & \\
Ethical/social implications & Education/communication plan \\
\hline
\end{tabular}

new drugs to be added to the formulary was used by 6 of the 10 committees. However, the type of information or evidence requested as part of the submission process differed (Table 2). Only 4 committees regularly conducted primary literature searches to identify evidence on clinical efficacy and safety (Table 3). In assessing the economic impact of new formulary drugs, budget impact analyses were more frequent than full economic evaluations (i.e., cost-effectiveness analyses).

\section{Formulary Review Decision-Making}

Decision-making for new formulary drug requests was accomplished by majority vote in 7 committees and by informal consensus in 3 committees. In 4 committees, new formulary drugs were given probationary approval, conditional on re-review after 3, 6, or 12 months. When a patient needed a nonformulary drug, 5 committees required completion of a nonformulary request form, and 7 committees monitored or evaluated nonformulary drug use across the institution, typically on a quarterly or annual basis. A formal or informal process to share formulary reviews with another P\&T committee was in place for $50 \%$ of the committees. Nonetheless, duplication of drug reviews across committees was demonstrated over the years 2010 and 2011 for selected new oral anticoagulants. During this period, 4 committees reviewed dabigatran for atrial fibrillation, and 5 committees reviewed rivaroxaban for venous thromboembolism prophylaxis in orthopedic surgery.

\section{P\&T Committee Member Survey}

\section{Respondents}

A total of 28 P\&T committee members returned completed questionnaires across the 10 committees, out of a potential maximum distribution of 50 individuals (based on the purposive sampling method described above). Respondents represented pharmacy (15 [54\%]), medicine (5 [18\%]), nursing (4 [14\%]), and other professions (4 [14\%]). The median number of years of practice in their respective professions was 19 (mean 19.6 years, range $2-40$ years), and respondents had a median of 5 years of experience as part of their committee (mean 6.8 years, range 1-25 years). Most respondents (22 [79\%]) had received some formal or structured training in pharmacology or therapeutics, and $14(50 \%)$ had received training in clinical epidemiology or evidence-based medicine. Fewer committee members had training in systematic literature reviews or meta-analysis (13 [46\%]), health economics (6 [21\%]), or health technology assessment (5 [18\%]). Training included courses or workshops; university undergraduate, graduate, or postgraduate training; medical residency; pharmacy residency; and medical school.

\section{Formulary Review Submission Process}

Almost 60\% (16/28 [57\%]) of the respondents agreed or strongly agreed that their institution's current process for new 
This single copy is for your personal, non-commercial use only.

For permission to reprint multiple copies or to order presentation-ready copies for distribution, contact CJHP at cjhpedit@cshp.ca

Table 3. Frequency of Evidence Synthesis and Evaluation Activities by Pharmacy and Therapeutics Committees

\begin{tabular}{|c|c|c|c|c|c|}
\hline \multirow[b]{2}{*}{ Statement } & \multicolumn{5}{|c|}{ No. $(\%)$ of Committees $(n=10)$} \\
\hline & Never & Rarely & Sometimes & Often & Always \\
\hline $\begin{array}{l}\text { Primary literature searches are typically conducted to identify } \\
\text { clinical efficacy and safety information }\end{array}$ & $0(0)$ & $1(10)$ & $5(50)$ & $2(20)$ & $2(20)$ \\
\hline $\begin{array}{l}\text { Systematic review methods and meta-analytic techniques are } \\
\text { used by the formulary review group to summarize the evidence* }\end{array}$ & $2(22)$ & $2(22)$ & $2(22)$ & $3(33)$ & $0 \quad(0)$ \\
\hline Economic evaluations are conducted internally & $3(30)$ & $3(30)$ & $2(20)$ & $1(10)$ & $1(10)$ \\
\hline Budget impact analyses are conducted internally & $3(30)$ & $0(0)$ & $3(30)$ & $3(30)$ & $1(10)$ \\
\hline
\end{tabular}

${ }^{*}$ One missing response; percentages are based on 9 committees.

\section{Table 4. Committee Members' Assessment of Submission Process for Formulary Review}

\section{Statement} Considering the current submission process for a new drug
formulary request, the process captures all of the information needed for the review.
How comfortable are you in evaluating the quality of the submission or the evidence provided?
Response; No. (\%) of Committee Members $(n=28)$

\begin{tabular}{ccccc}
$\begin{array}{c}\text { Strongly } \\
\text { disagree }\end{array}$ & Disagree & $\begin{array}{c}\text { Neither } \\
\text { agree or } \\
\text { disagree }\end{array}$ & Agree & $\begin{array}{c}\text { Strongly } \\
\text { agree }\end{array}$ \\
$3(11)$ & $6(21)$ & $3(11)$ & $15(54)$ & $1(4)$ \\
\hline Uncomfortable & $\begin{array}{c}\text { Slightly } \\
\text { comfortable } \\
\text { (4) }\end{array}$ & $\begin{array}{c}\text { Moderately } \\
\text { comfortable }\end{array}$ & $\begin{array}{c}\text { Very } \\
\text { comfortable }\end{array}$ & $\begin{array}{c}\text { Extremely } \\
\text { comfortable }\end{array}$ \\
$13(46)$ & $7(25)$ & $3(11)$ \\
\hline Unsatisfied & $\begin{array}{c}\text { Slightly } \\
\text { satisfied }\end{array}$ & $\begin{array}{c}\text { Moderately } \\
\text { satisfied }\end{array}$ & $\begin{array}{c}\text { Very } \\
\text { satisfied }\end{array}$ & $\begin{array}{c}\text { Extremely } \\
\text { satisfied }\end{array}$ \\
$6(21)$ & $1(4)$ & $13(46)$ & $8(29)$ & $0(0)$ \\
\hline
\end{tabular}

drug formulary requests captured all of the information needed for formulary review, yet half of respondents were only moderately comfortable evaluating the quality of the submission (Table 4). Respondents were more confident in the adequacy of the clinical evidence for decision-making relative to the economic evidence or organizational impact analyses (Figure 1). Nineteen (68\%) of the respondents indicated that their respective committees did not have sufficient clinical and economic expertise to make a fully informed decision for all formulary requests. The most commonly cited areas of missing expertise were health economics, physician participation, and evidence or critical appraisal. Other impediments noted were limited resources, staff, and administrative support; limited or complete lack of information; incomplete or brief submissions; and time constraints.

\section{Potential for Coordinated Review Process}

The use of national or provincial formulary reviews and recommendations was strongly supported (Table 5). In addition, respondents noted potential benefits and drawbacks that would be realized by harmonizing or centralizing formulary review processes within the LHIN. The most commonly reported themes regarding possible benefits were efficiency in terms of sharing workload or costs, more standardization or reduction in variation, and improvement in quality or expertise in review. Respondents also identified several drawbacks, such as concerns about addressing institution-specific population, needs, and priorities; equity across large and small sites; physician autonomy or buy-in; the time and cost of implementation; and institutionspecific budget impact.

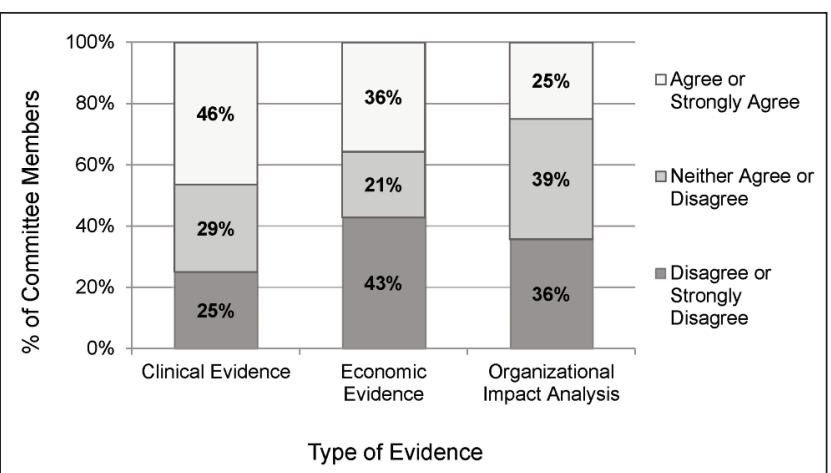

Figure 1. Committee members' level of agreement as to whether evidence provided in formulary submissions is sufficiently comprehensive and detailed for decisionmaking, by type of evidence $(n=28)$.

\section{DISCUSSION}

To the authors' knowledge, no previous studies have explored formulary review processes across a LHIN. A recent survey showed increased efforts by provincial health authorities and hospitals across Canada to collaborate and share resources to support formulary decision-making. ${ }^{15}$ These initiatives have included developing formal and informal processes to share drug reviews between institutions, establishing provincial hospital formularies, and creating committees to make decisions for both public drug plans and hospital formularies; however, several challenges in aligning hospital formularies with regional or provincial health plans have been identified. ${ }^{15}$ 
This single copy is for your personal, non-commercial use only.

For permission to reprint multiple copies or to order presentation-ready copies for distribution, contact CJHP at cjhpedit@cshp.ca

Table 5. Committee Members' Level of Agreement with Concepts Relating to Coordinated Drug Review Processes

\begin{tabular}{|c|c|c|c|c|c|}
\hline \multirow[b]{2}{*}{ Statement } & \multicolumn{5}{|c|}{ No. $(\%)$ of Committee Members $(n=28)$} \\
\hline & $\begin{array}{l}\text { Strongly } \\
\text { Disagree }\end{array}$ & Disagree & $\begin{array}{l}\text { Neither } \\
\text { Agree nor } \\
\text { Disagree }\end{array}$ & Agree & $\begin{array}{l}\text { Strongly } \\
\text { Agree }\end{array}$ \\
\hline $\begin{array}{l}\text { A standardized drug formulary submission process across } \\
\text { institutions in the LHIN would be beneficial. }\end{array}$ & $1(4)$ & $14(4)$ & $1(4)$ & $16(57)$ & $9(32)$ \\
\hline $\begin{array}{l}\text { A common drug formulary across institutions in the LHIN } \\
\text { would be beneficial. }\end{array}$ & $1(4)$ & $5(18)$ & $4(14)$ & $12(43)$ & $6(21)$ \\
\hline $\begin{array}{l}\text { The institutional formularies should be synchronized with } \\
\text { Ontario Drug Benefit drug formulary listings. }\end{array}$ & $2(7)$ & $5(18)$ & $5(18)$ & $10(36)$ & $6(21)$ \\
\hline $\begin{array}{l}\text { The Ontario Public Drug Program should expand } \\
\text { its formulary process to evaluate and decide on } \\
\text { reimbursement for hospital-only drugs. }\end{array}$ & $0(0)$ & $0 \quad(0)$ & $7(25)$ & $13(46)$ & $8(29)$ \\
\hline $\begin{array}{l}\text { National and provincial formulary reviews should be used } \\
\text { to inform institutional formulary decisions. }\end{array}$ & $1(4)$ & $\begin{array}{ll}0 & (0)\end{array}$ & 1 (4) & $14(50)$ & $12(43)$ \\
\hline
\end{tabular}

The P\&T committees in the HNHB LHNIN were similar in structure to others in Canada and internationally $8,11,16,17$ and were active in traditional activities of assessing the clinical benefits and harms of new drugs proposed for addition to their formularies; they have also expanded their oversight to cover several risk mitigation and medication safety areas. The expertise within each committee, and therefore the quality of formulary review, differed. In addition, nearly 1 FTE was spent on formulary review processes, a conservative estimate that does not account for all of the committee review time contributed voluntarily. In recognition of the higher-quality review and efficiencies in shared expertise, workload, and costs, nearly $90 \%$ of individual respondents supported a centralized review process. A centralized process would be of greater importance to smaller community hospitals than to larger academic institutions. ${ }^{17}$ Despite the advantages of centralizing the formulary review process, respondents were wary that institution-specific population needs or priorities might not be adequately addressed. In a debate about centralizing formulary management and pharmacy services in general, Slobodan and others ${ }^{18}$ outlined the advantages of taking a broader perspective, including consistency in pharmacy services, funding, and access to medications and drug information resources. However, Wilson ${ }^{19}$ raised concerns that a centralized process might impede a hospital's ability to respond to the needs of local patients in a timely manner or to be innovative with the adoption of new drugs or reallocation of resources; he noted, however, that processes currently in place could alleviate these concerns.

Similar to the findings of other North American studies, ${ }^{11,20}$ the current survey showed that considerations of value for money are not well developed, usually consisting of basic analyses of budgetary impact. A full economic evaluation, to determine the cost-effectiveness of a new drug relative to current alternatives, is required to understand whether the drug under consideration will offer good value for money and what other hospital programs or services will need to be forgone to fund the drug. ${ }^{21}$ Similar to the results of previous studies, ${ }^{22-26}$ the use of economic evaluations in the HNHB LHIN was constrained by a shortage of expertise, as well as limited time and resources available to collect, analyze, and review economic data.

The response rate for the institution profile survey was excellent, with all 10 hospital corporations completing the survey. Nonetheless, this study had several limitations. Despite purposive sampling of 4 or 5 P\&T committee members representing different professions from each institution, there was an overrepresentation of pharmacists in the committee member survey. As such, the representativeness of the medicine and nursing responses may be limited by the small number of responses from people in these professions. Second, the generalizability of the survey responses beyond this particular LHIN is uncertain. For example, 35\% of the sites within HNHB LHIN were academic teaching centres, which may not be representative of other areas in the province. In terms of generalizability to other parts of Canada, this survey may provide some insight into the regionalization of formulary reviews and potential alignment of formularies across hospitals within a geographic area, given the ongoing trend toward increased collaboration and coordination of formulary decision-making processes across Canada. ${ }^{15}$ Third, only a limited amount of information was requested in the questionnaire, as a way to encourage completion. The survey did not address the organizational challenges of implementing a regional hospital formulary and the associated administrative processes, although there was agreement among committee members that a common drug formulary across institutions would be beneficial. Future research is needed to further explore the pros, cons, and feasibility of centralized formulary review and the potential for a common regional formulary.

\section{CONCLUSION}

Formulary review for new drugs is duplicated in hospitals across the HNHB LHIN, with considerable utilization of time and resources. There was strong support for centralized formulary 
review, for better use of high-quality provincial and national evidence reviews and recommendations. A gap exists in terms of health economic or health technology assessment expertise for new drug formulary reviews by P\&T committees in this LHIN.

\section{References}

1. Prescribed drug spending in Canada, 2013: a focus on public drug programs. Ottawa (ON): Canadian Institute for Health Information; 2015.

2. Drivers of prescription drug spending in Canada. Ottawa (ON): Canadian Institute for Health Information; 2012.

3. Health system funding reform. Quality-based procedures. Toronto $(\mathrm{ON})$ : Ontario Ministry of Health and Long-Term Care; 2015 [cited 2015 Jun 30]. Available from: www.health.gov.on.ca/en/pro/programs/ecfa/funding/hs_ funding_qbp.aspx

4. Tierney M, Manns B. Optimizing the use of prescription drugs in Canada through the Common Drug Review. CMAJ. 2008;178(4):432-5.

5. National health expenditure trends, 1975 to 2014. Ottawa (ON): Canadian Institute for Health Information; 2014.

6. Paris V, Docteur E. Pharmaceutical pricing and reimbursement policies in Canada. OECD Health Working Papers 24. Paris (France): Organisation for Economic Co-operation and Development; 2007 Feb 15 [cited 2015 Jun 30]. Available from: www.oecd.org/canada/37868186.pdf

7. American Society of Health-System Pharmacists. ASHP statement on the pharmacy and therapeutics committee and the formulary system. Am J Health Syst Pharm. 2008;65(24):2384-6.

8. Durán-García E, Santos-Ramos B, Puigventos-Latorre F, Ortega A. Literature review on the structure and operation of pharmacy and therapeutics committees. Int J Clin Pharm. 2011;33(3):475-83.

9. Mamdami M, Paterson M, Laupacis A, Handa K, Jacka R. Hospital funding for new drug technologies. Toronto (ON): Institute for Clinical Evaluative Sciences; 2002 [cited 2015 Jun 30]. Available from: www.ices.on.ca/ Publications/Atlases-and-Reports/2002/Hospital-funding-for-new-drugtechnologies

10. Loorand-Stiver L. Hospital-based pharmacy and therapeutics committees: evolving responsibilities and membership. Environmental Scan Report 23. Ottawa (ON): Canadian Agency for Drugs and Technologies in Health; 2011.

11. Mittmann N, Knowles S. A survey of pharmacy and therapeutic committees across Canada: scope and responsibilities. Can J Clin Pharmacol. 2009;16(1):e171-7.

12. Ontario Ministry of Health and Long-term Care. Legislation: Transparent Drug System for Patients Act, 2006. Toronto (ON): Queen's Printer for Ontario; 2012 [cited 2015 Jun 30]. Available from: www.health.gov.on.ca/ en/common/legislation/bill102/

13. Ontario's LHINs. Toronto (ON): Queen's Printer for Ontario; 2014 [cited 2015 Oct 20]. Available from: www.lhins.on.cal

14. Ontario Ministry of Health and Long-term Care. Legislation: Local Health System Integration Act, 2006. Toronto (ON): Queen's Printer for Ontario; 2012 [cited 2015 Oct 20]. Available from: www.health.gov.on.ca/en/ common/legislation/lhins/defaultaspx

15. Pant S, Sherwood V, Chelak K. Hospital formularies decision-making process. Environmental Scan Report 47. Ottawa (ON): Canadian Agency for Drugs and Technologies in Health; 2015.

16. Pedersen CA, Schneider PJ, Scheckelhoff DJ. ASHP national survey of pharmacy practice in hospital settings: prescribing and transcribing - 2013. Am J Health Syst Pharm. 2014;71(11):924-42.

17. Shalansky SJ, Virk R, Ackman M, Jackevicius C, Kertland H, Tsuyuki R, et al. Access to new cardiovascular therapies in Canadian hospitals: a national survey of the formulary process. Can J Cardiol. 2003;19(2):173-9.

18. Slobodan J, van Haaften D, Chambers C. Is a single provincial pharmacy program beneficial for the advancement of pharmacy practice? The "pro" side. Can J Hosp Pharm. 2011;64(4):285-6.

19. Wilson B. Is a single provincial pharmacy program beneficial for the advancement of pharmacy practice? The "con" side. Can J Hosp Pharm. 2011;64(4): 286-7.
20. Mannebach MA, Ascione FJ, Gaither CA, Bagozzi RP, Cohen IA, Ryan ML. Activities, functions, and structure of pharmacy and therapeutics committees in large teaching hospitals. Am J Health Syst Pharm. 1999;56(7):622-8.

21. McGregor M, Brophy JM. End-user involvement in health technology assessment (HTA) development: a way to increase impact. Int J Technol Assess Health Care. 2005;21(2):263-7.

22. Anell A, Svarvar P. Pharmacoeconomics and clinical practice guidelines. A survey of attitudes in Swedish formulary committees. Pharmacoeconomics. 2000;17(2):175-85.

23. Spath HM, Charavel M, Morelle M, Carrere MO. A qualitative approach to the use of economic data in the selection of medicines for hospital formularies: a French survey. Pharm World Sci. 2003;25(6):269-75.

24. van Gool K, Gallego G, Haas M, Viney R, Hall J, Ward R. Economic evidence at the local level: options for making it more useful. Pharmacoeconomics. 2007;25(12):1055-62.

25. van Velden ME, Severens JL, Novak A. Economic evaluations of healthcare programmes and decision making: the influence of economic evaluations on different healthcare decision-making levels. Pharmacoeconomics. 2005;23(11): 1075-82.

26. Williams IP, Bryan S. Cost-effectiveness analysis and formulary decision making in England: findings from research. Soc Sci Med. 2007;65(10):2116-29

Natasha Burke, MSc, is with McMaster University and St Joseph's Healthcare Hamilton (Programs for Assessment of Technology in Health [PATH]), Hamilton, Ontario

James M Bowen, RPh, BScPhm, MSc, is with McMaster University and St Joseph's Healthcare Hamilton (Programs for Assessment of Technology in Health [PATH]), Hamilton, Ontario.

Sue Troyan is with St Joseph's Healthcare Hamilton, Hamilton, Ontario.

Jathishinie Jegathisawaran, MHEcon, was, at the time of this study, with McMaster University and St Joseph's Healthcare Hamilton (Programs for Assessment of Technology in Health [PATH]), Hamilton, Ontario.

Carolyn Gosse, RPh, ACPR, PharmD, is with St Joseph's Healthcare Hamilton, Hamilton, Ontario.

Marita Tonkin, RPh, BScPhm, PharmD, ACPR, is with Hamilton Health Sciences, Hamilton, Ontario.

Sandra Kagoma, DiplPharm, BScPharm, MBA/HCM, is with Brant Community Healthcare System, Brantford, Ontario.

Ron Goeree, MA, is with McMaster University, Hamilton, Ontario.

Anne Holbrook, MD, PharmD, MSC, FRCPC, is with McMaster University and St Joseph's Healthcare Hamilton, Hamilton, Ontario.

Competing interests: Anne Holbrook has received honoraria from the Ontario Ministry of Health and Long-Term Care for work on drug policy. No other competing interests were declared.

\section{Address correspondence to:}

Natasha Burke

Programs for Assessment of Technology in Health (PATH)

St Joseph's Healthcare Hamilton/McMaster University

25 Main Street West, Suite 2000

Hamilton ON L8P $1 \mathrm{H} 1$

e-mail: nburke@mcmaster.ca

Funding: This research was funded by an Academic Health Sciences Centres Alternate Funding Plan (AFP) Innovation Fund grant awarded to Anne Holbrook. 